\title{
PENAFSIRAN SEBARAN BATUBARA DENGAN METODE SEISMIK REFLEKSI DI DAERAH TEBO TENGAH, KABUPATEN TEBO, PROVINSI JAMBI
}

INTERPRETATION OF COAL DISTRIBUSION USING REFLECTION SEISMIC METHOD AT TEBO TENGAH AREA, TEBO REGENCY, JAMBI PROVINCE

\section{Teuku Ishlah dan Syuhada Arsadipoera}

Perekayasa Madya Pusat Sumber Daya Geologi

Jalan Soekarno-Hatta No.444, Bandung

teukuislah@yahoo.co.id

diterima : 2 Februari 2014

direvisi : 14 April 2014

disetujui : 28 April 2014

\section{ABSTRAK}

Batubara di bawah kedalaman 400 m merupakan endapan yang belum banyak dieksploitasi di Indonesia. Potensi ini umumnya masuk dalam kelas hipotetik dan sangat bermanfaat untuk pengusahaan tambang dalam. Untuk meningkatkan status sumber daya batubara diperlukan beragam penyelidikan dalam akuisisi data diantaranya berupa penyelidikan seismik refleksi dan pemboran eksplorasi. Penelitian ini memakai metoda seismik refleksi untuk mendeteksi lapisan batubara di bawah permukaan. Hasil penyelidikan seismik refleksi di daerah Tebo Tengah mampu mengindikasikan sebanyak lima lapisan batubara yang terdapat dalam tiga formasi namun dengan ketebalan yang belum bisa ditentukan.

Kata kunci : batubara, perlapisan, seismik refleksi.

\section{ABSTRACT}

Coal deposits under $400 \mathrm{~m}$ below the surface are still uxploited in Indonesia. These potential resources are generally included in hyphotetic class and useful for underground mining exploitation. To increase the status of current coal resources, it is necessary to carry out several investigations for data acquisition such as geophysyical seismic reflection and borehole exploration. This paper utilizes seismic reflection method to detect coal deposits far below the surface. The results of seismic reflection investigation in Tebo Tengah area are able to indicate as many as five coal seams within three formations while the thickness can not be determined

Keywords : coal, seam, seismic reflection.

\section{PENDAHULUAN}

Batubara di Indonesia tersebar cukup luas terutama di pulau Sumatera dan Kalimantan, serta ditemukan di pulau Jawa dan pulau Sulawesi dalam jumlah yang terbatas. Data batubara yang terungkap umumnya berupa batubara permukaan sampai kedalaman $100 \mathrm{~m}$. Sedangkan batubara yang terletak pada kedalaman lebih dari $100 \mathrm{~m}$ (deep seated coal) masih belum banyak diketahui (Darman \& Sidi, 2000).

Anonim (2013) menjelaskan bahwa berdasarkan data status sumber daya dan cadangan batubara tahun 2012, sumber daya batubara hipotetik di Indonesia mencapai 32,950 miliar ton dari total sumber daya batubara 119,445 miliar ton. Klasifikasi tereka juga masih tinggi yakni mencapai 35,407 miliar ton. Klasifikasi sumber daya dan cadangan ditentukan oleh tingkat keakuratan data geologi, kerapatan informasi geologi, metoda geofisika yang pernah dilakukan dan tingkat kompleksitas tektonik/struktur geologi. Untuk meningkatkan klasifikasi sumber daya dan cadangan batubara, beserta endapan batubara di bawah 
permukaan diperlukan pengeboran eksplorasi dan penyelidikan geofisika.

Dalam penelitian ini digunakan salah satu metode geofisika yakni penyelidikan seismik refleksiyang sangat jarang dilakukan untuk endapan batubara, karena batubara banyak yang tersingkap di permukaan bumi dan penambangan batubara baru mencapai kedalaman 100 meter untuk tambang terbuka. Dengan berkembangnya teknologi eksplorasi menggunakan metode seismik, maka metode ini dapat dipakai untuk menemukan endapan batubara di bawah permukaan. Metoda ini diharapkandapat menambah keyakinan geologi suatu daerah prospek endapan batubara bawah permukaan untuk pengembangan penambangan batubara tambang dalam dan gas metana batubara serta mineral lainnya.

Secara regional, berdasarkan Peta Geologi Lembar Muara Bungo-Sumatera (Simanjuntak, dkk., 1994) daerah penyelidikan berada pada batas antara Cekungan Sumatera Selatan dan Cekungan Sumatera Tengah yang keduanya merupakan cekungan pendalaman belakang (backdeep basin) yang dibatasi oleh tinggian Bukit Tigapuluh (Koesoemadinata dan Hardjono, 1978).

Urutan stratigrafi regional dibagi atas tiga kelompok, yaitu kelompok Pra Tersier, terdiri atas Formasi Terantam (Karbon Awal), Formasi Gangsal, Formasi Pengabuhan, Formasi Mentulu (Permokarbon), Formasi Mengkarang (Perm Awal) dan Formasi Pelepat (Perm Awal - Tengah). Kelompok Tersier, terdiri atas Formasi Lahat dan Formasi Kelesa (Eosen - Oligosen Awal), Formasi Talangakar dan Formasi Lahat (Oligosen Akhir - Miosen Awal), Formasi Gumai (Miosen Awal - Tengah), Formasi Airbenakat (Miosen Tengah - Akhir), Formasi Muaraenim (Miosen Akhir Pliosen Awal) dan Formasi Kasai (Plio Plistosen). Kelompok yang ketiga adalah kelompok Kuarter, tersusun oleh batuan produk gunungapi, endapan undak sungai, endapan rawa dan aluvium. Di samping itu, di daerah ini juga terdapat batuan-batuan terobosan dengan kisaran umur JuraKuarter yang terdiri atas Pluton Granit,
Granit, Pegmatit, Diorit, Granodiorit, Dasit dan Syenit.

\section{Lokasi Daerah Penyelidikan}

Daerah Tebo Tengah dan sekitarnya secara administratif termasuk dalam wilayah Kabupaten Tebo, Provinsi Jambi yang secara geografis terletak pada kordinat $01^{\circ} 15^{\prime}-01^{\circ} 30^{\prime}$ lintang selatan dan $102^{\circ} 30^{\prime}-102^{\circ} 45^{\prime}$ bujur timur. Daerah penyelidikan dapat dicapai dari Kota Jambi ke lokasi dengan jalan darat (Gambar 1).

Stratigrafi daerah penyelidikan tersusun oleh batuan sedimen Tersier, batuan Pra - Tersier yang menempati bagian Timurlaut dan Endapan Kuarter yang melampar di bagian Selatan di sepanjang daerah aliran Sungai Batanghari. Endapan Pra Tersier terdiri atas Formasi Gangsal berumur Perm dan batuan terobosan Granit berumur Jura. Sedimen Tersier terdiri atas Formasi Lahat, Formasi Talangakar, Formasi Gumai, Formasi Airbenakat dan Formasi Muaraenim. Endapan Kuarter adalah Formasi Kasai dan Aluvium. Formasi pembawa endapan batubara di daerah penyelidikan adalah; Formasi Talangakar, Formasi Airbenakat, Formasi Muaraenim dan Formasi Kasai. Akan tetapi, formasi yang diperkirakan memiliki potensi yang cukup besar sebagai formasi pembawa batubara adalah Formasi Muaraenim yang dibagi atas empat anggota, yaitu Anggota M1, M2, M3 dan M4. Tiap anggota terdiri dari beberapa lapisan batubara dan batas antar anggota ditentukan oleh alas (floor) dan puncak (top) dari lapisan batubara. Anggota M1 terdiri dari dua lapisan batubara/seam yang dinamakan Keladi dan Merapi. Anggota M2 mengandung tiga seam yaitu Petai, Suban, Mangus yang dapat dibedakan atas Mangus-1 dan Mangus-2. Anggota M3 terdiri dari dua seam yaitu Burung dan Benuang, dan Anggota M4 terdiri dari empat seam yaitu Kebon, Benaka/Enim, Lematang/Jelawatan dan Niru. Di samping seam-seam tersebut pada beberapa anggota sering terdapat beberapa lapisan batubara relatif tipis dan tidak menerus yang dinamakan lapisanlapisan gantung.

Anggota M1 bagian bawahnya dibatasi oleh alas dari seam Keladi dan 
batas atas dibatasi seam Petai. Anggota M2 batas bawahnya adalah alas seam Petai dan batas atasnya puncak seam Mangus. Anggota M3 batas bawah adalah puncak seam Mangus dan batas atas adalah alas seam Kebon. Anggota M4 batas bawahnya alas seam Kebon dan batas atas adalah puncak seam Niru. Keberadaan anggota maupun lapisanlapisan batubara tersebut di atas tidak selalu dijumpai secara lengkap pada setiap tempat pada sekuen Formasi Muaraenim, hal ini tergantung pada kondisi pengendapan, posisi pada cekungan dan aspek geologi lainnya (De Coster, 1974).

Bentang alam di daerah
penyelidikan terdiri dari satuan morfologi perbukitan terjal, perbukitan bergelombang dan pendataran. Satuan morfologi perbukitan terjal ketinggian berkisar antara 200 - 500 mdpl terdapat di bagian Timurlaut yang ditempati oleh batuan dari kelompok Pra Tersier. Satuan morfologi perbukitan bergelombang sedang menempati sebagian besar wilayah penyelidikan dan umumnya ditempati oleh batuan sedimen Tersier. Satuan pedataran melampar di bagian Selatan di sepanjang aliran Sungai Batanghari dan ditempati oleh endapan Kuarter (Gambar 2).

Struktur geologi di daerah penyelidikan berupa lipatan dan sesar. Lipatan berupa antiklin dan sinklin berarah
Baratlaut-Tenggara, sedangkan sesar berupa sesar naik berarah relatif sejajar dengan lipatan yaitu Baratlaut-Tenggara dan sesar normal berarah Utara-Selatan. Sesar normal umumnya memotong sumbu perlipatan atau sesar naik, dimensinya lebih kecil sehingga disimpulkan sebagai sesar-sesar lokal yang terbentuk kemudian (Simanjuntak, dkk., 1994).

\section{Maksud dan Tujuan}

Penyelidikan seismik refleksi endapan batubara di daerah Tebo Tengah dan sekitarnya, khususnya di wilayah Desa Mangupeh dan Desa Muara Kilis Kecamatan Ilir Tengah, Kabupaten Tebo Provinsi Jambi dimaksudkan untuk menambah informasi data potensi endapan batubara bawah permukaan sehingga dapat diketahui pola pelamparan, ketebalan lapisan, dan bentuk geometris dari endapan batubara pada kedalaman lebih besar dari $400 \mathrm{~m}$. Tujuan penelitian ini adalah untuk mengetahui sebaran batubara pada kedalaman lebih dari $400 \mathrm{~m}$ di daerah penyelidikan dan sekitarnya dalam rangka inventarisasi endapan batubara bersistem di Cekungan Sumatera Selatan, melengkapi basis data (database) potensi endapan batubara Indonesia dan kemungkinan pengembangan gas metana batubara (CBM).

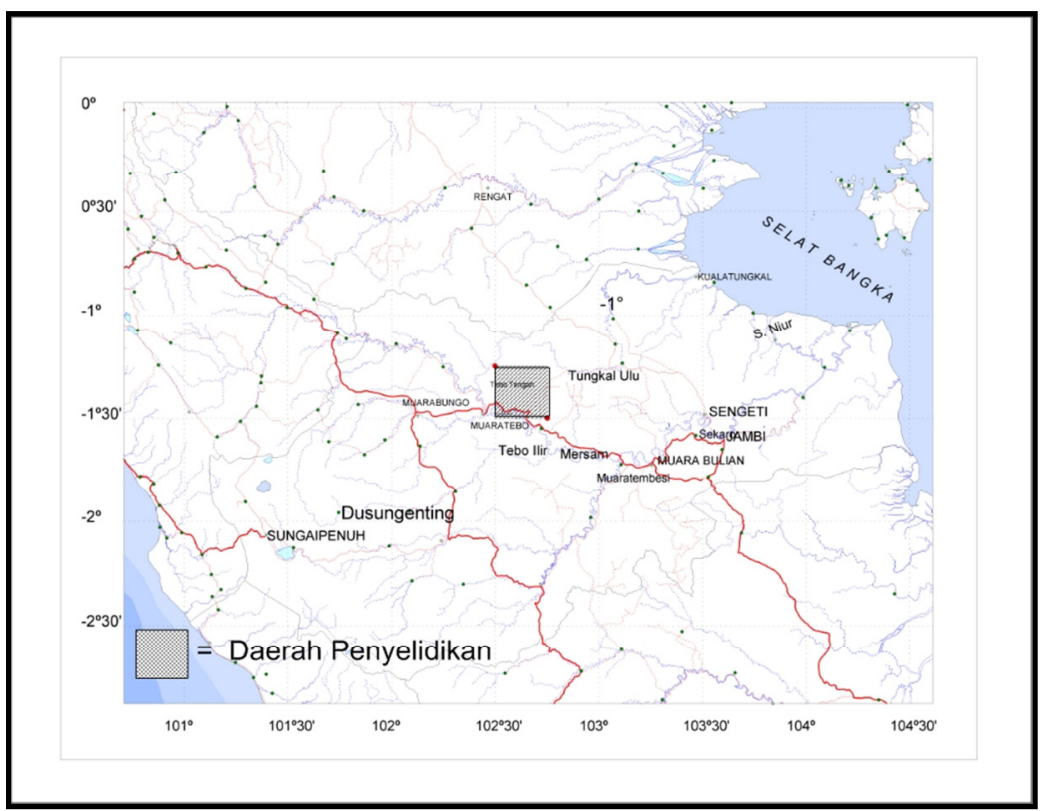

Gambar 1. Lokasi Daerah Penyelidikan Seismik Refleksi Tebo Tengah, Kecamatan HilirTengah, Kabupaten Tebo, Provinsi Jambi. 


\section{MAKALAH ILMIAH}

\section{METODE PENYELIDIKAN}

Secara umum kegiatan akuisisi data seismik refleksi dimulai dengan membuat sumber getar buatan, misalnya dengan vibrator atau ledakan dinamit. Kemudian gelombang getar yang timbul dideteksi dan direkam dengan alat penerima, seperti geophone atau hydrophone (Gambar 3). Getaran hasil ledakan akan menembus ke dalam lapisanlapisan sedimen dibawah permukaan bumi yang sebagian dari getaran gelombang tersebut akan diteruskan ke kedalaman dan sebagian akan dipantulkan kembali ke permukaan oleh reflektor/bidang pantul. Sinyal yang dipantulkan kembali akan direkam oleh alat perekam yang diletakkan di permukaan. Sedangkan sinyal yang menembus lapisan bumi akan dipantulkan kembali oleh bidang pantul yang kedua, sinyalnya akan diterima kembali oleh alat perekam dipermukaan dan seterusnya hingga terakhir ke alat perekam. Alat perekam akan menghasilkan data jejak seismik (trace seismic).

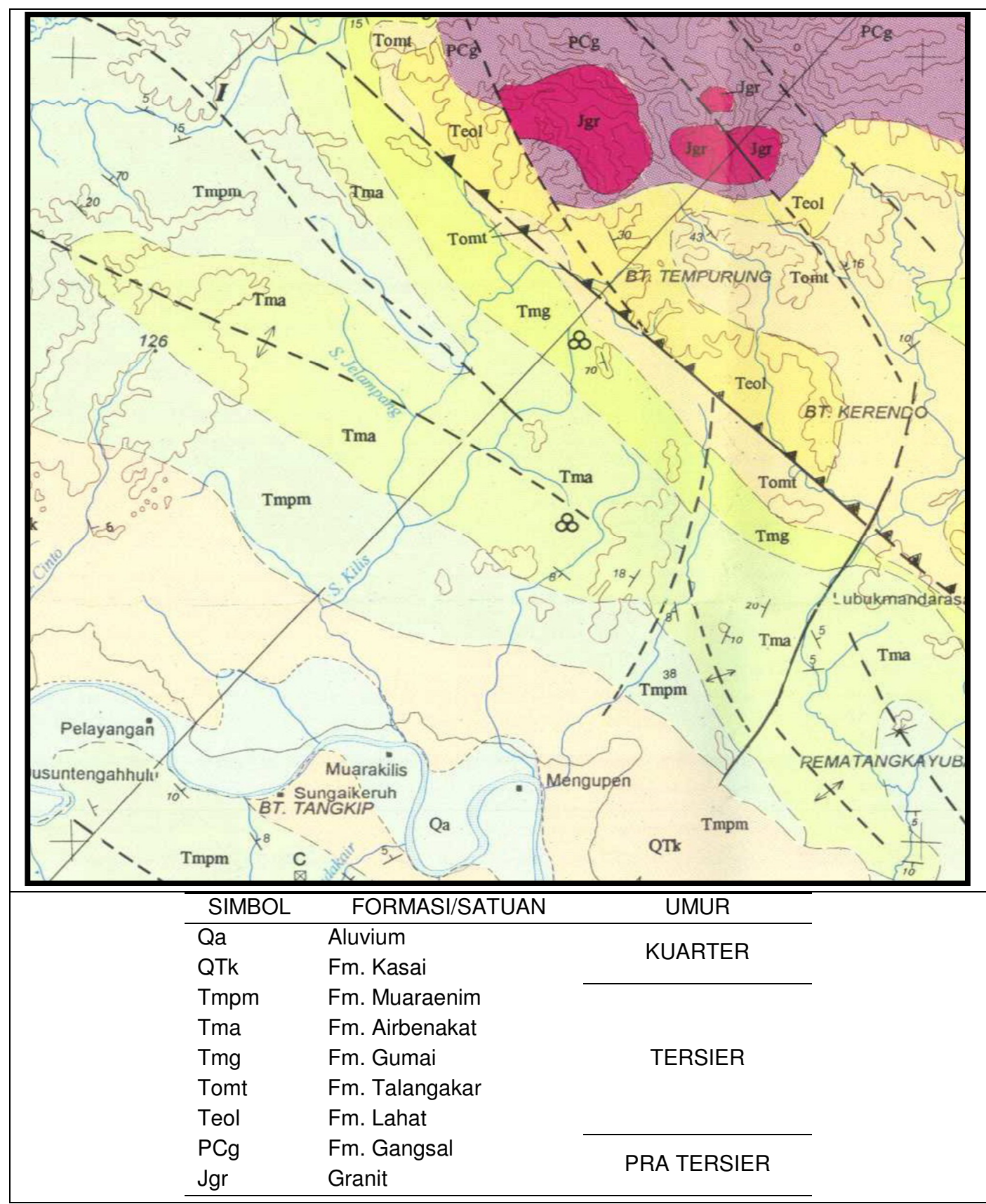

Gambar 2. Peta Geologi Daerah Penyelidikan (Modifikasi dari Simanjuntak, dkk., 1994). 


\section{MAKALAH ILMIAH}

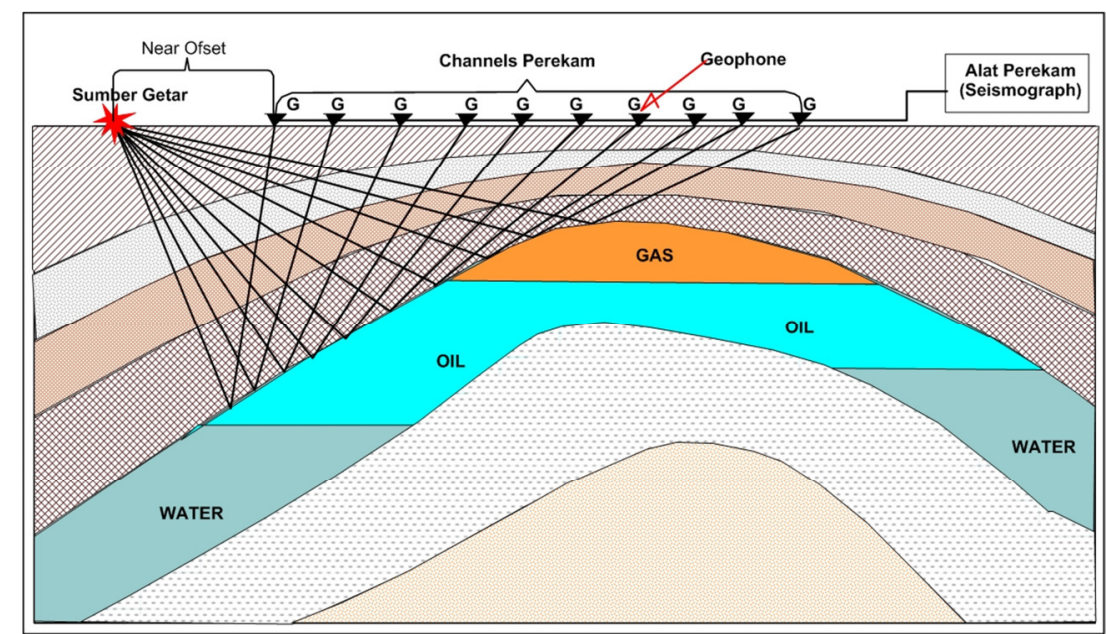

Gambar 3. Ilustrasi konfigurasi pengambilan data seismik refleksi di darat.

(Lyatsky \& Lawton, 1998).

Secara umum tata cara kegiatan dalam operasi penyelidikan seismik refleksi dapat dijelaskan berikut:

1. Pelaksanaan tes parameter akuisisi agar survey optimal yang diperoleh berupa interval shot point (SP), Interval receiver, interval shot line, interval Receiver line, Kedalaman lubang SP, banyaknya bahan peledak yang dipakai, gain yang digunakan, fold coverage, channel yang aktif dalam satu penembakan, jumlah geophone per grup.

2. Pembuatan desain survei koordinat teoritik dari titik-titik tembak dan posisi geophone receiver.

3. Pengukuran dan pemberian tanda terhadap kordinat titik tembak dan geophone receiver oleh bersamaan dengan pembukaan akses jalan, pemindahan (offset dan kompensasi) titik tembak jika ditemukan penghambat dalam survei serta pembuatan jembatan apabila diperlukan guna pergerakan orang dan peralatan pada lintasan ukur.

4. Pembentangan (spread) kabel dan pemasangan geophone untuk kondisi permukaan yang kering dan hydrophone untuk kondisi berair/ rawa.

5. Perekaman dengan melakukan penembakan pada titik tembak (shot point) dan mengaktifkan receiver dengan jumlah channel yang aktif disesuaikan dengan hasil tes parameter yang dilakukan. Sebelum penembakan dilakukan, ada petugas yang bertugas untuk penghentian bising yang disebabkan oleh aktifitas orang atau hewan. Kontrol kualitas data rekaman, untuk memastikan data telah memenuhi syarat atau malah perlu dilakukan penembakan ulang.

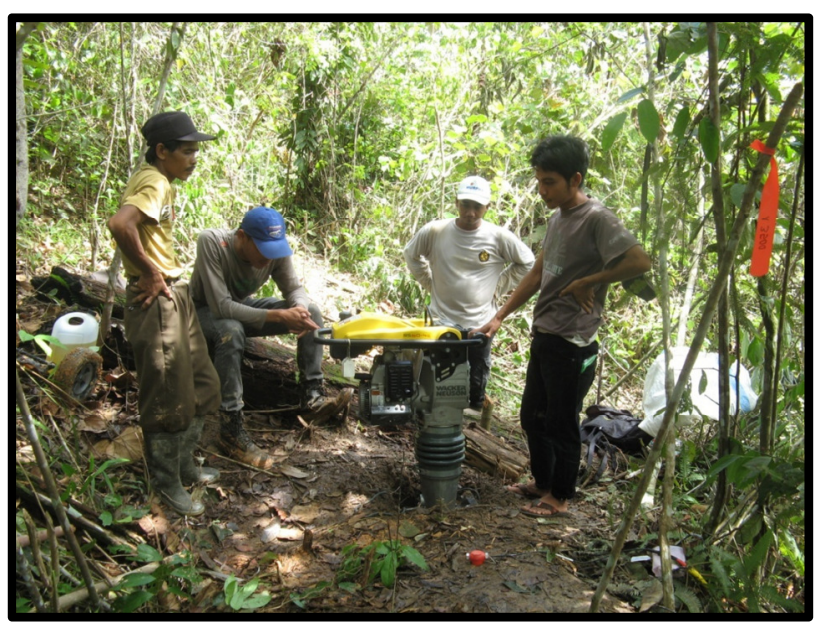

Gambar 4. Alat seismik untuk Membangkitkan Gelombang 


\section{MAKALAH ILMIAH}

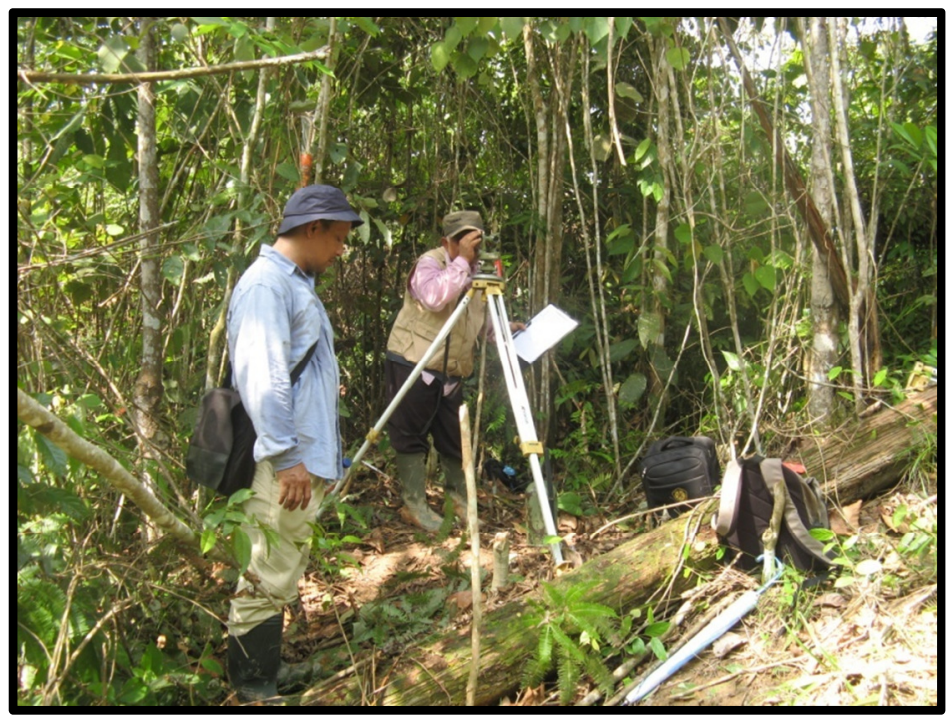

Gambar 5. Suasana Pengukuran Lintasan A pada Posisi A.3500.

\section{HASIL PENYELIDIKAN}

\section{Titik Ukur}

Pengukuran seismik refleksi di daerah penyelidikan dilaksanakan sebanyak dua lintasan ukur A dan C dengan susunan bentangan geophone dengan shot point dilakukan dengan end off spread, interval geophone $15 \mathrm{~m}$, near offset $15 \mathrm{~m}$. Pengukuran dilakukan tegak lurus arah umum struktur perlapisan batuan sedimen sehingga arah lintasan pengukuran berarah baratdaya-timurlaut dengan panjang lintasan masing-masing sekitar $2 \mathrm{Km}$. Jumlah titik shot yang diukur adalah 300 shot dimana setiap shot dilakukan 3-4 kali stack. Banyaknya stack dalam satu shot tergantung dari kualitas data yang dihasilkan, apabila dengan tiga stack masih belum cukup, maka ditambahkan lagi satu stack. Lintasan A berarah baratdaya-timurlaut (Gambar 7) atau tegak lurus dengan arah umum struktur geologi dan berada pada kondisi tanah yang berawa. Dalam pengukuran seismik refleksi ini digunakan Peta Rupabumi Indonesia skala 1:50.000 lembar Muara Kilis (091451) yang dikeluarkan oleh Bakosurtanal pada tahun 1991.
Lintasan yang pada rencana awal berarah sejajar dengan struktur geologi dirubah menjadi lintasan $C$ yang tegak lurus dengan struktur dan berjarak satu kilometer dari lintasan A. Lintasan C ini berada di sepanjang jalan masuk ke area pertambangan batubara (Gambar 6). Hal ini dilakukan karena pada saat pengukuran di Lintasan A dengan kondisi tanah berawa, data yang dihasilkan kurang bagus sehingga untuk Lintasan $C$ di pindahkan ke lokasi yang mempunyai kondisi tanah yang kompak dan bukan lahan urugan.

Kualitas data yang dihasilkan pada lintasan A sebagian besar cukup baik, kecuali pada beberapa titik shot yang berada di rawa, bahkan sebagian titik shot yang berada di rawa diabaikan. Kualitas data yang dihasilkan pada lintasan $C$ lebih baik daripada data di lintasan $A$. Pada lintasan A, tampak bahwa hasil pengukuran lebih banyak noise pada kedalaman dangkal sedangkan pada lintasan $\mathrm{C}$, noise berkurang. Faktor struktur geologi juga sangat menentukan, apalagi letak pengukuran berada pada antara dua cekungan (Gambar 8). 


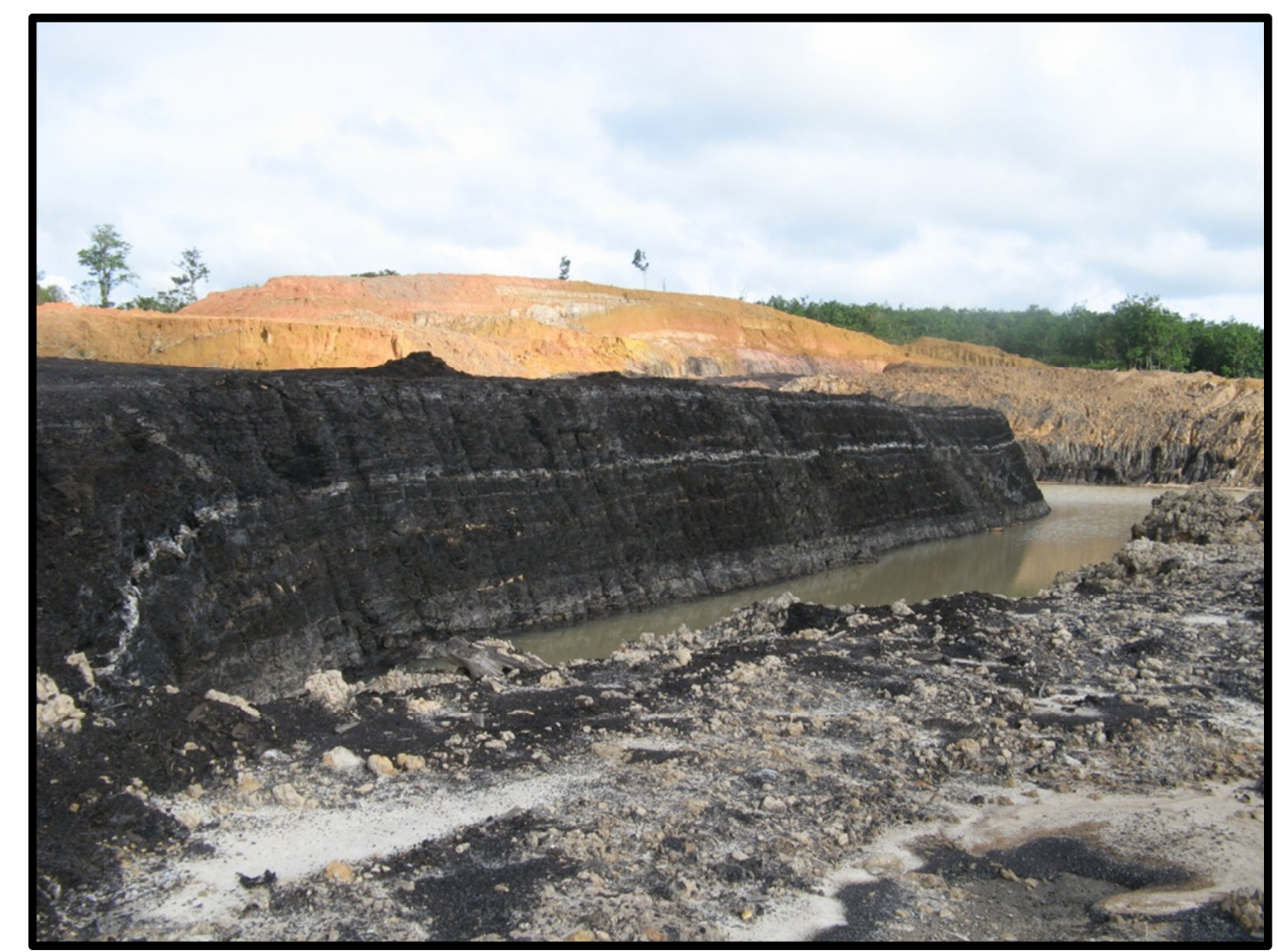

Gambar 6. Contoh Tambang Terbuka $\pm 100 \mathrm{~m}$ dari Lintasan C di Desa Mangupeh

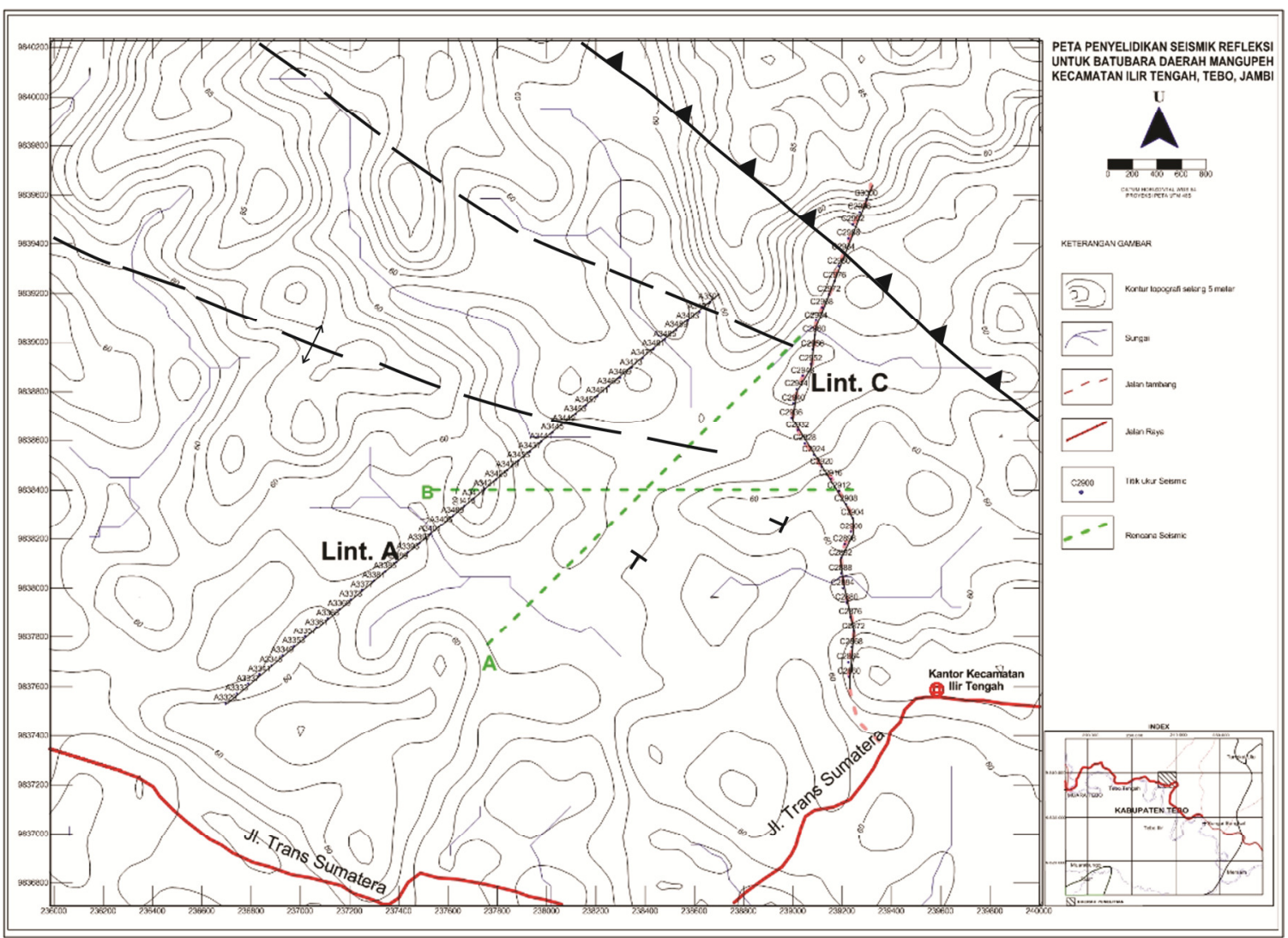

Gambar 7. Peta lintasan survei seismik refleksi di daerah penyelidikan 


\section{MAKALAH ILMIAH}

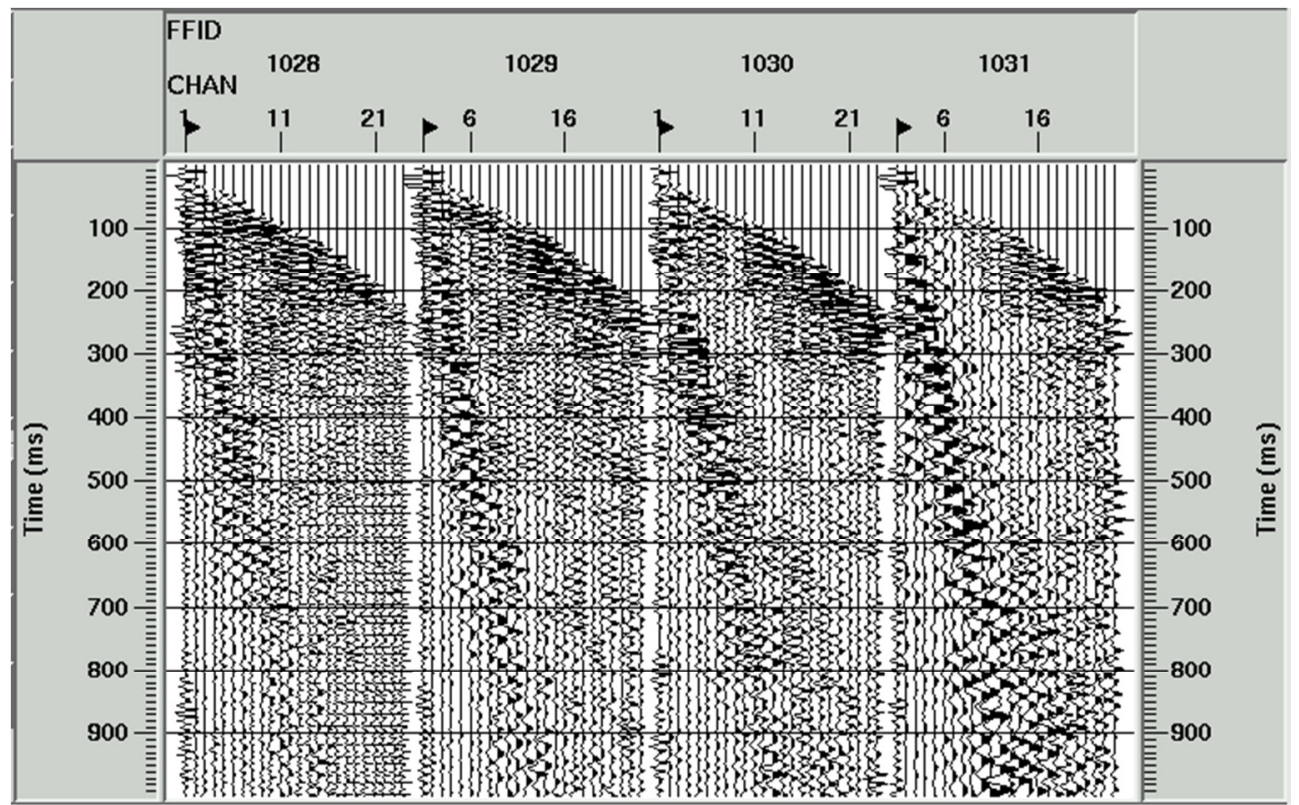

( a )

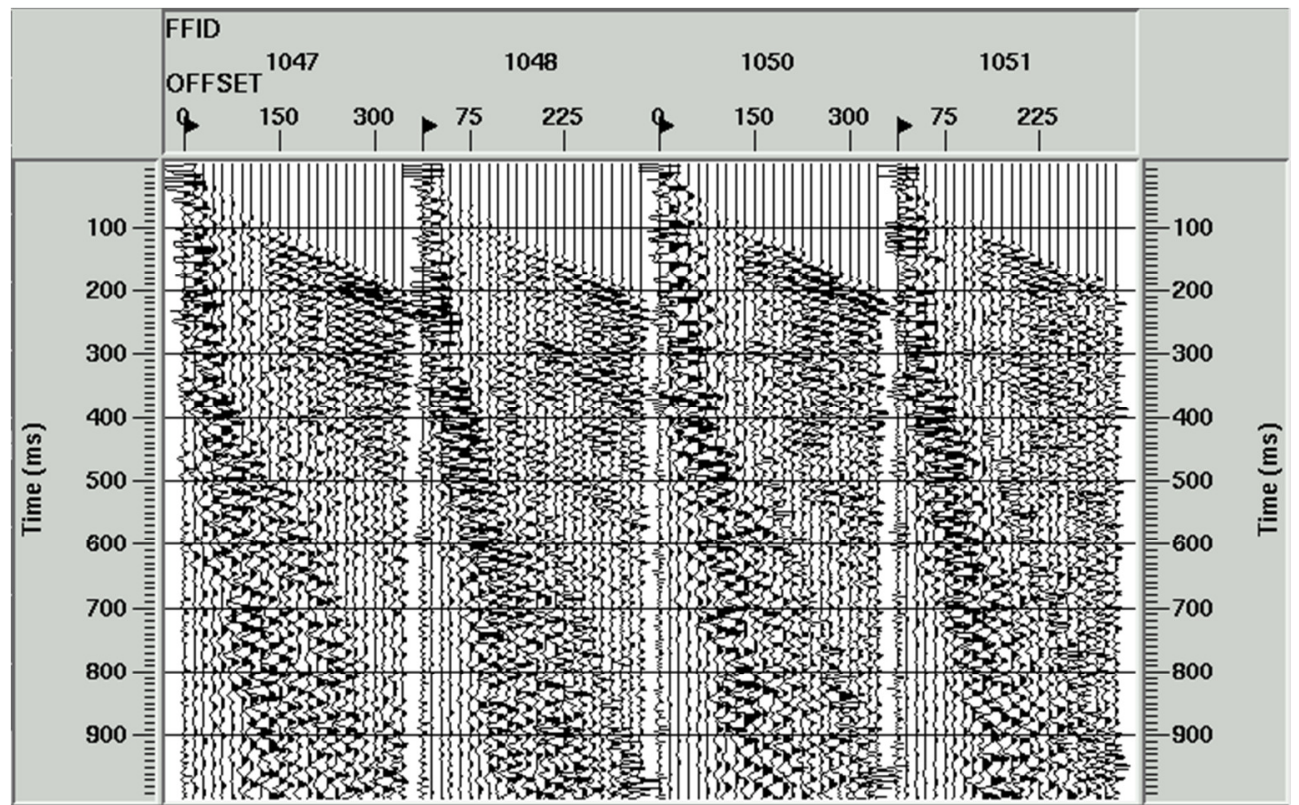

( b )

Gambar 8. (a) Shot gather lintasan A, (b) shot gather lintasan C.

\section{Pengambilan Data Lapangan}

Uji parameter berupa uji noise, uji source, uji filter, dan uji gain dilakukan sebelum pengukuran di lintasan pada beberapa lokasi shot dan berulang-ulang sampai didapatkan parameter terbaik untuk diterapkan di semua lokasi shot. Hasil uji adalah sebagai berikut:

\begin{tabular}{lc}
\hline Jumlah channel & 24 \\
record length & $1.5 \mathrm{~s}$ \\
\hline
\end{tabular}

\begin{tabular}{lc}
\hline Sampling interval & $2 \mathrm{~ms}$ \\
Sweep length & $30.5 \mathrm{~s}$ \\
High cut & out \\
Pre-amp gain & Taper 3 channel low \\
& gain \\
Spasi geophone & $15 \mathrm{~m}$ \\
Spasi shot point & $30 \mathrm{~m}$ \\
Stack/shot point & $3-4$ stack \\
Shot configuration & End-off spread \\
Near offset & $15 \mathrm{~m}$ \\
Far offset & $360 \mathrm{~m}$ \\
Panjang Lintasan A & $2130 \mathrm{~m}$ \\
Panjang Lintasan C & $2205 \mathrm{~m}$ \\
\hline
\end{tabular}




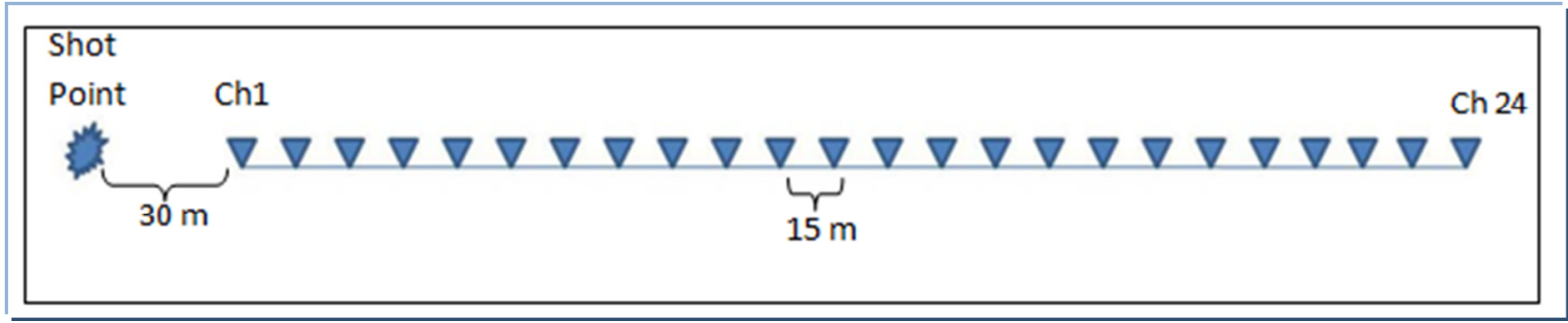

Gambar 9. Ilustrasi konfigurasi penembakan end-off spread.

\section{Pemrosesan Data}

Tahapan proses data seismik refleksi dibagi menjadi tiga yaitu preprocessing, processing, dan postprocessing. Selain data lapangan dalam format SEG (SEG-Y, SEG-D, SEG-B), perlu dipersiapkan juga data pendukung lainnya seperti observer report, koordinat shot point (SP), dan koordinat geophone.Tahapan Pre-processing yang pertama adalah TAR (true amplitude recovery) yang bertujuan untuk mengembalikan nilai amplitudo sinyal dari sumber getar ke nilai aslinya. Karena semakin dalam penetrasi maka sinyal dari sumber getar yang ditangkap geophone akan semakin lemah. Oleh karenanya diperlukan analisis kecepatan, koreksi statik residual. Untuk menganalisa kecepatan gelombang digunakan metode semblance yang akan menghasilkan kecepatan perataan (rms). Kecepatan optimum pada reflektor dengan kontur yang tinggi. Pencuplikan kecepatan dilakukan setiap 20 CDP (Common Depth Point, berjarak 200 meter) pada data supergather yaitu data 11 CDP Gather yang di stack dengan tujuan menguatkan sinyal dan mereduksi noise.

Seiring dengan berubahnya nilai kecepatan setelah dilakukan analisis kecepatan, maka nilai statik pun akan berubah. Untuk itu perlu dilakukan perhitungan ulang statik lagi untuk mendapatkan nilai koreksi statik residual. Koreksi statik residual dilakukan dengan membuat window pada data stack. Kemudian akan dilakukan perhitungan matematis yang menghasilkan nilai koreksi statik residual. Pada pemrosesan data ini, window yang dibuat adalah 7 CDP secara lateral dan 300 ms secara vertikal. Nilai koreksi ini kemudian diaplikasikan terhadap data CDP Gather dan distack untuk dibandingkan dengan data penampang sebelum koreksi statik residual. Selanjutnya, data CDP Gather dibersihkan dari noise dengan lebih kuat. Utamanya pembersihan, dilakukan untuk random noise sehingga diharapkan data penampang memiliki kemenerusan yang lebih baik.

Hal yang sangat penting dalam prosesing data seismik ini adalah migrasi data. Migrasi data dilakukan dengan tujuan mengembalikan reflektor ke lokasi sebenarnya atau menghilangkan difraksi yang diakibatkan efek kemiringan pada data topografi. Difraksi dihilangkan karena bisa mengecoh pada saat interpretasi data penampang. Untuk data ini migrasi yang dilakukan adalah post stack time migration dengan metode Kirchoff (Diessel, 1984).

Data hasil migrasi dapat mempertegas keberadaan reflektor seperti yang terlihat pada gambar 10 dan Gambar 11. Penampang ini merupakan produk akhir dari processing data seismik refleksi. 


\section{MAKALAH ILMIAH}

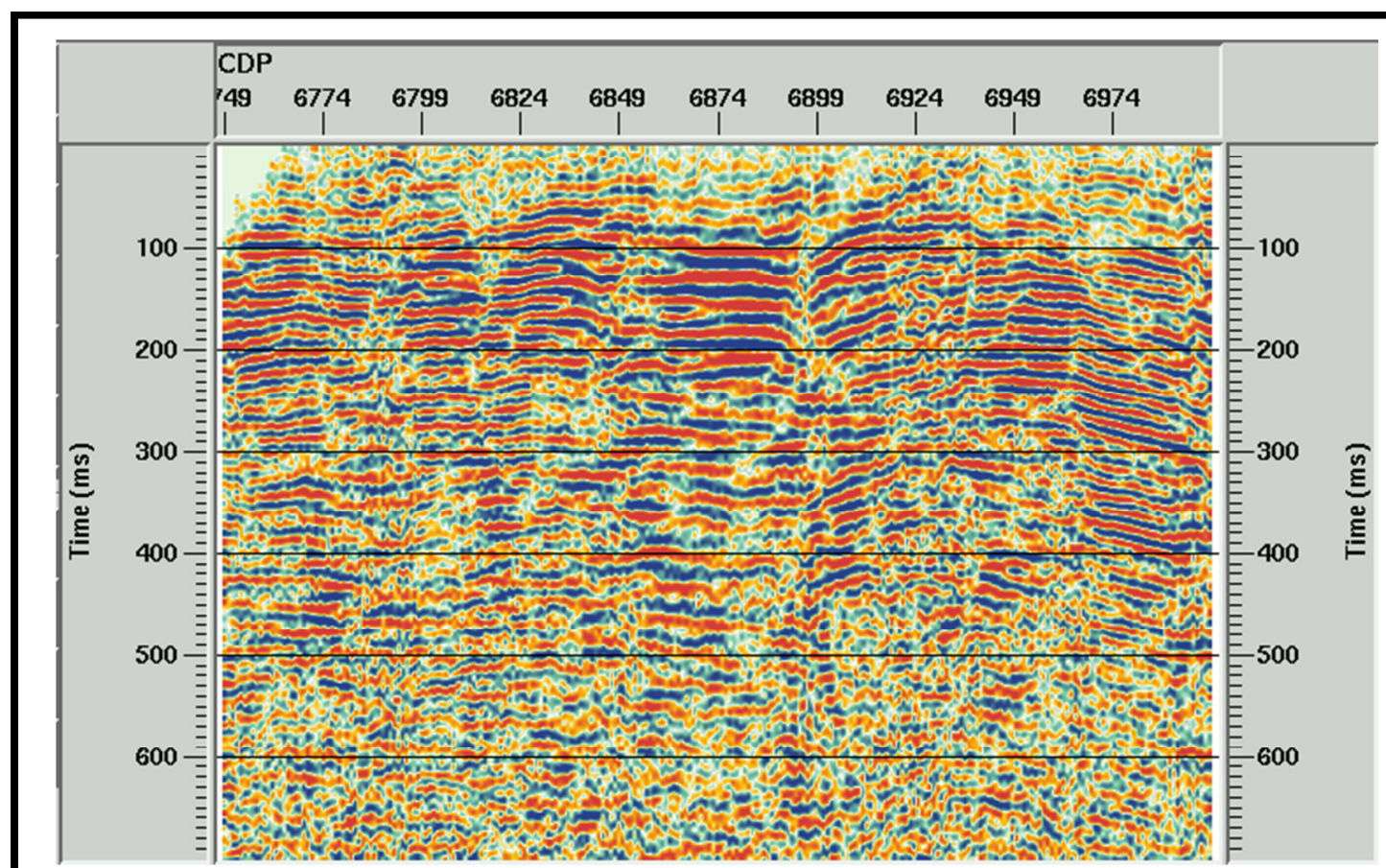

(a)

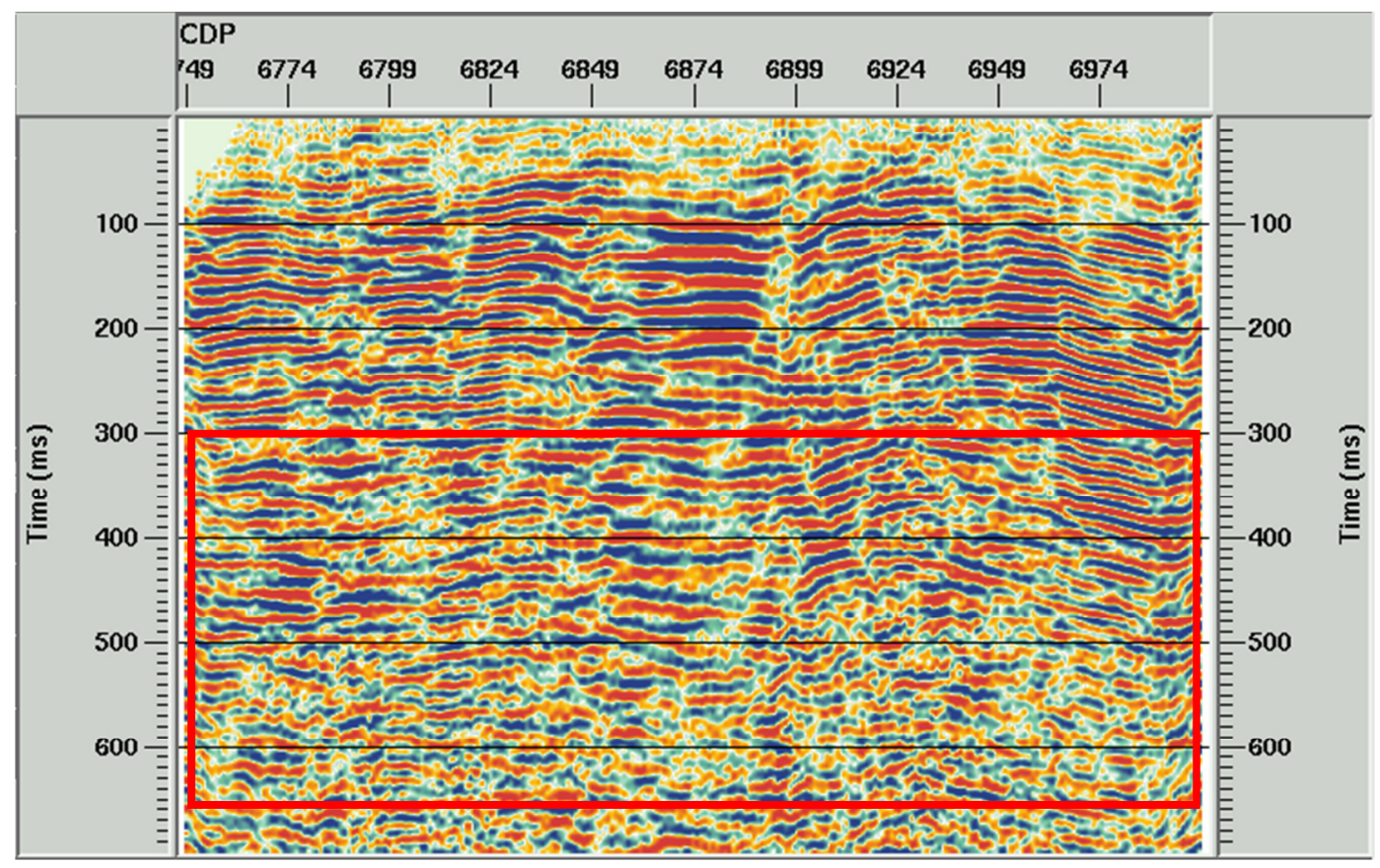

(b)

Gambar 10. Penampang Lintasan A (a) sebelum migrasi, (b) setelah migrasi. 


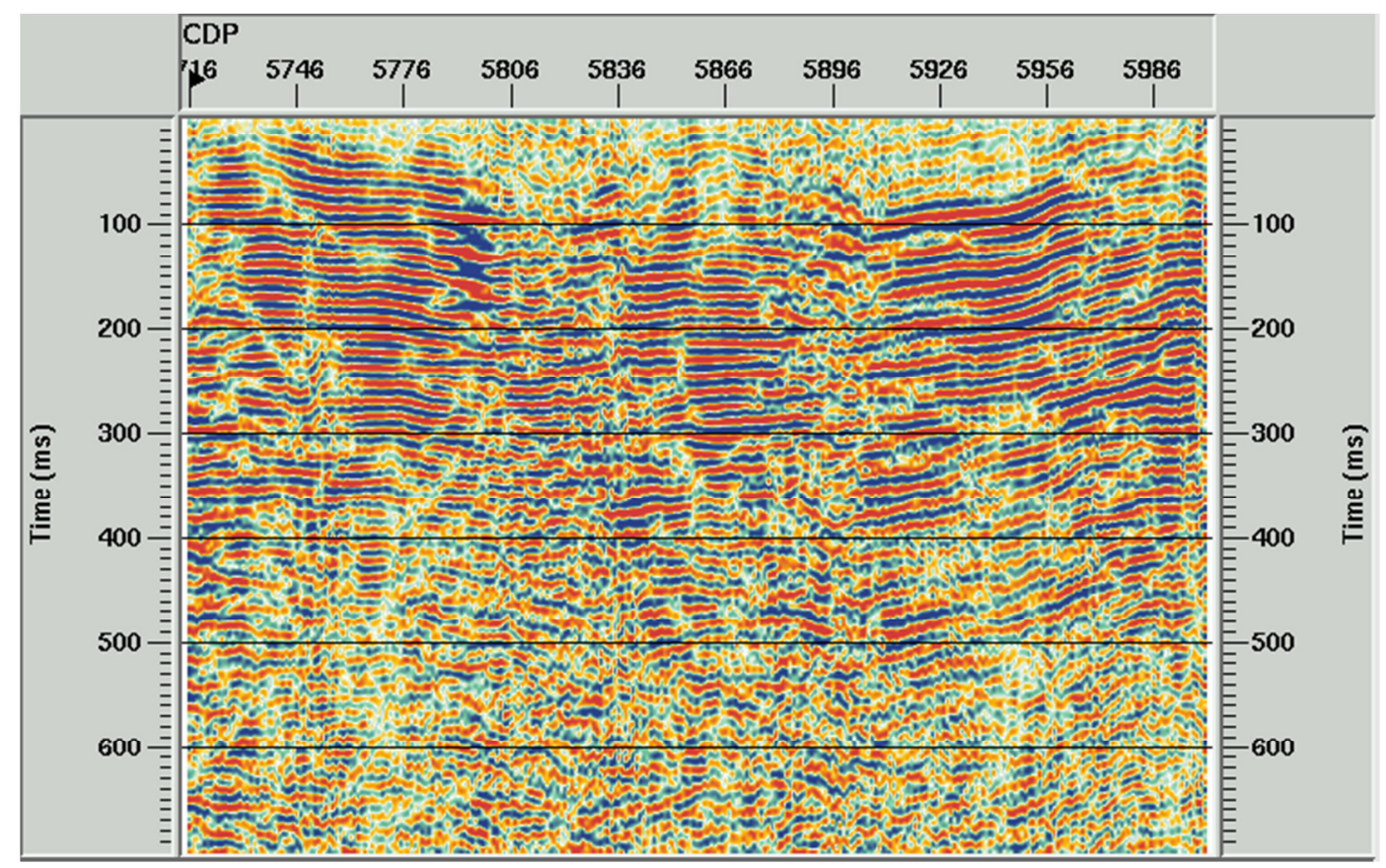

(a)

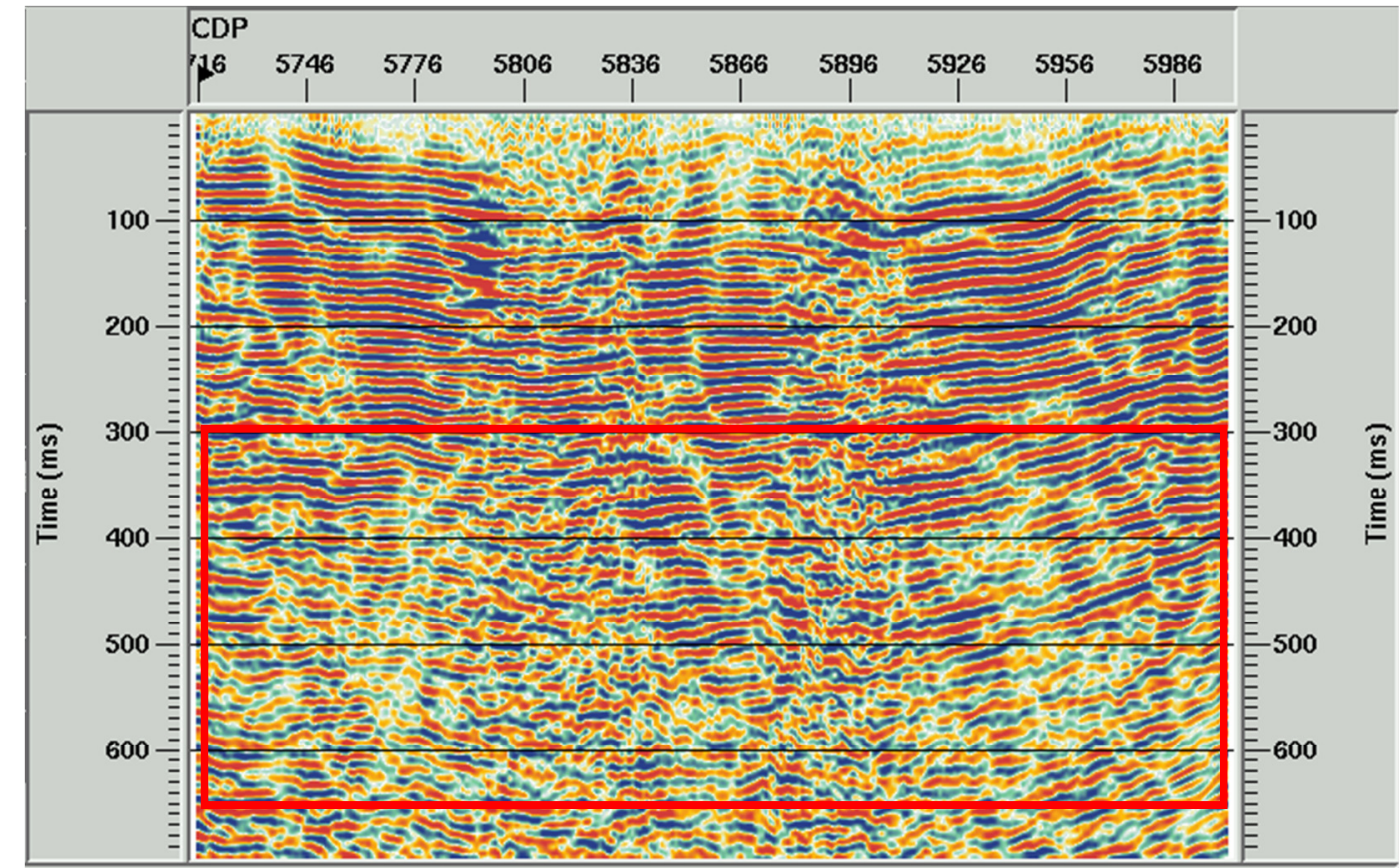

(b)

Gambar 11. Penampang Lintasan C (a) sebelum migrasi, (b) setelah migrasi

\section{PEMBAHASAN}

Jumlah panjang lintasan ukur seismik refleksi yang telah diselesaikan di daerah penyelidikan mencapai $4.335 \mathrm{~m}$.. Lintasan ukur seismik refleksi lebih difokuskan pada kondisi tanah padat dan kering seperti misalnya sepanjang jalan setapak atau jalan masuk ke areal pertambangan yang telah dikupas tanah penutupnya dan diperkeras dengan batu kerikil.

"Depth Section" (penampang kedalaman) dari lintasan $A$ dan lintasan $B$ sebagai hasil akhir dari pemrosesan data memberikan informasi terdapat beberapa 


\section{MAKALAH ILMIAH}

indikasi lapisan batubara yang dicirikan dengan kemenerusan besaran amplitudo yang sama dan kecerahan tampilannya dari pada lapisan lain yang tergambar (Lyatsky dan Lawton, 1988).

Proses penafsiran penampang kedalaman dari hasil akhir processing data adalah dengan cara membedakan berdasarkan kemenerusan besaran amplitudo yang sama (walaupun terputusputus) dan kecerahan tampilannya yang kemudian dibandingkan dengan hasil penafsiran penampang geologi daerah penyelidikan. Penampang kedalaman seismik dapat memberikan gambaran tiga formasi batuan dan ditafsirkan terdapat lima lapisan batubara yang terkandung di dalamnya.

Hasil ahir prosesing data yang berupa penampang kedalaman ditafsirkan seperti berikut:

\section{Penampang Kedalaman Lintasan A}

Penampang ini (Gambar 12) memberikan gambaran pendeteksian sampai kedalaman lebih dari $450 \mathrm{~m}$ dari permukaan tanah dan diperkirakan terdapat lima lapisan batubara (coal 1 coal 5) yang ketebalannya tidak dapat ditentukan (Tabel 1).

Dari permukaan tanah sampai dengan kedalaman $40 \mathrm{~m}$ ditafsirkan sebagai tanah penutup hasil pelapukan batuan, pada kedalaman ini tidak tergambar informasi adanya kemenerusan besaran amplitudo dan kecerahan tampilannya, kemungkinan besar ini diakibatkan oleh sifat fisik batuan yang sangat lambat meneruskan gelombang getar sehingga pada saat prosesing data menghasilkan zona buram.

Tabel 1. Penafsiran Lapisan Batubara pada Lintasan A

\begin{tabular}{llc}
\hline \multicolumn{1}{c}{ Nama Lapisan } & \multicolumn{1}{c}{ Kedalaman } & Formasi \\
\hline Lapisan batubara 5 (coal 5) & Berundulasi di kedalaman 50-100 m & Kasai \\
Lapisan batubara 4 (coal 4) & Berundulasi di kedalaman 120-140 m & Muara Enim \\
Lapisan batubara 3 (coal 3) & Berundulasi di kedalaman 180-220 m & Muara Enim \\
Lapisan batubara 2 (coal 2) & Berundulasi di kedalaman 250-280 m & Muara Enim \\
Lapisan batubara 1 (coal 1) & Berundulasi di kedalaman 350-450 m & Airbenakat \\
\hline
\end{tabular}

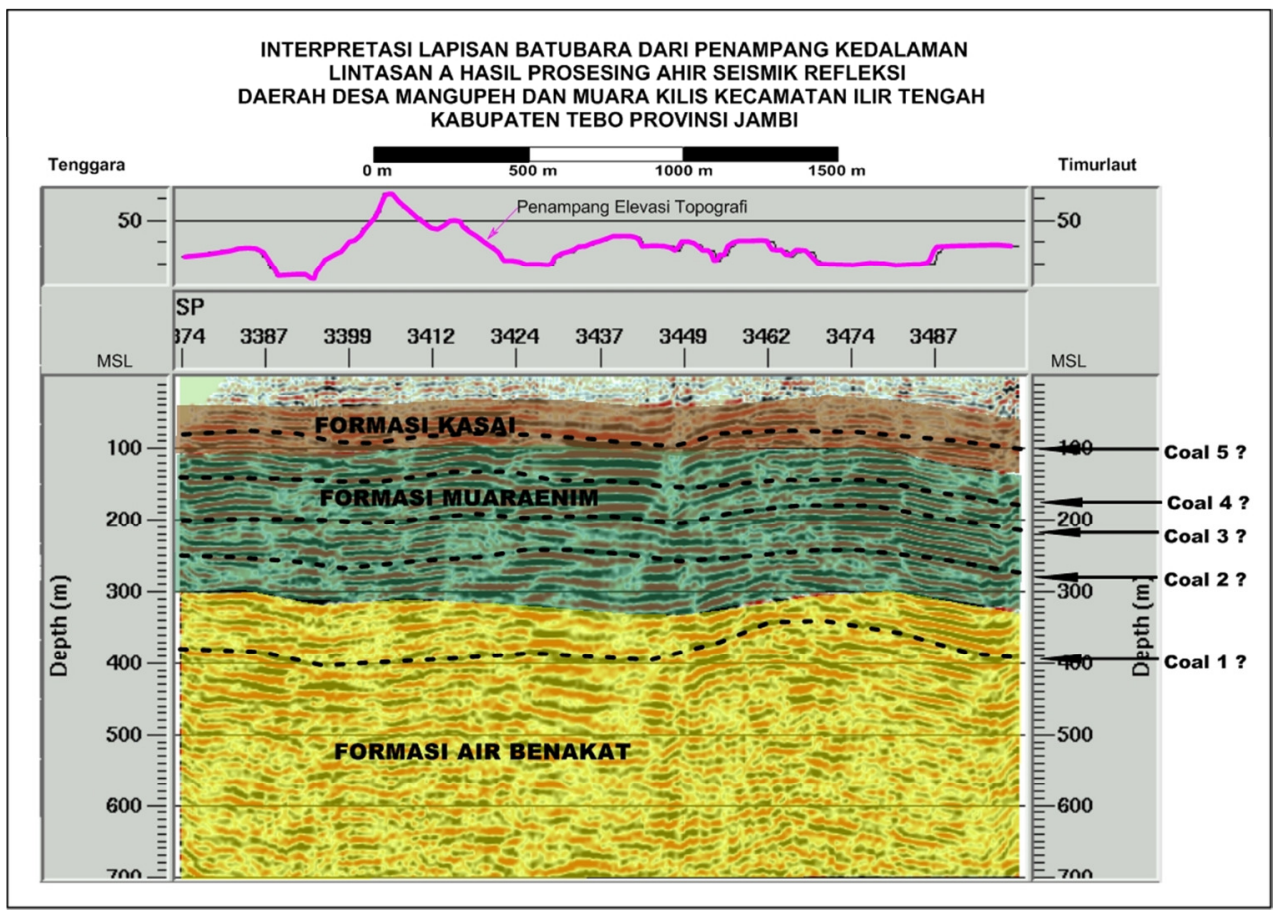

Gambar 12 Pendugaan Lapisan Batubara Lintasan A. 


\section{Penampang Kedalaman Lintasan C}

Penampang ini (Gambar 13) memberikan gambaran pendeteksian sampai kedalaman lebih dari $450 \mathrm{~m}$ dari permukaan tanah yang diperkirakan terdapat lima lapisan batubara (coal 1 coal 5) yang ketebalan lapisan batubara tidak dapat ditentukan(Tabel 2).

Dari permukaan tanah sampai dengan kedalaman $40 \mathrm{~m}$ ditafsirkan sebagai tanah penutup hasil pelapukan batuan, pada kedalaman ini tidak tergambar informasi adanya kemenerusan besaran amplitudo dan kecerahan tampilannya, kemungkinan besar ini diakibatkan oleh sifat fisik batuan yang sangat lambat meneruskan gelombang getar sehingga pada saat prosesing data menghasilkan zona buram.

Penampang lintasan $\mathrm{C}$ memberikan gambaran adanya zona cepat rambat gelombang rendah secara tegak pada posisi titik ukur C.2940 - C.2955 (lebar lebih dari $75 \mathrm{~m}$ ) namun tidak tampak adanya offset, ini ditafsirkan sebagai akibat keberadaan struktur geologi berupa struktur patahan/sesar.

Tabel 2. Penafsiran Lapisan Batubara pada Lintasan C

\begin{tabular}{ccc}
\hline Nama Lapisan & \multicolumn{1}{c}{ Kedalaman } & Formasi \\
\hline Lapisan batubara 5 (coal 5) & Berundulasi di kedalaman 40-70 m & Kasai \\
Lapisan batubara 4 (coal 4) & Berundulasi di kedalaman 100-120 m & Muara Enim \\
Lapisan batubara 3 (coal 3) & Berundulasi di kedalaman 200-220 m & Muara Enim \\
Lapisan batubara 2 (coal 2) & Berundulasi di kedalaman 300-320 m & Muara Enim \\
Lapisan batubara 1 (coal 1) & Berundulasi di kedalaman 380-470 m & Airbenakat \\
\hline
\end{tabular}

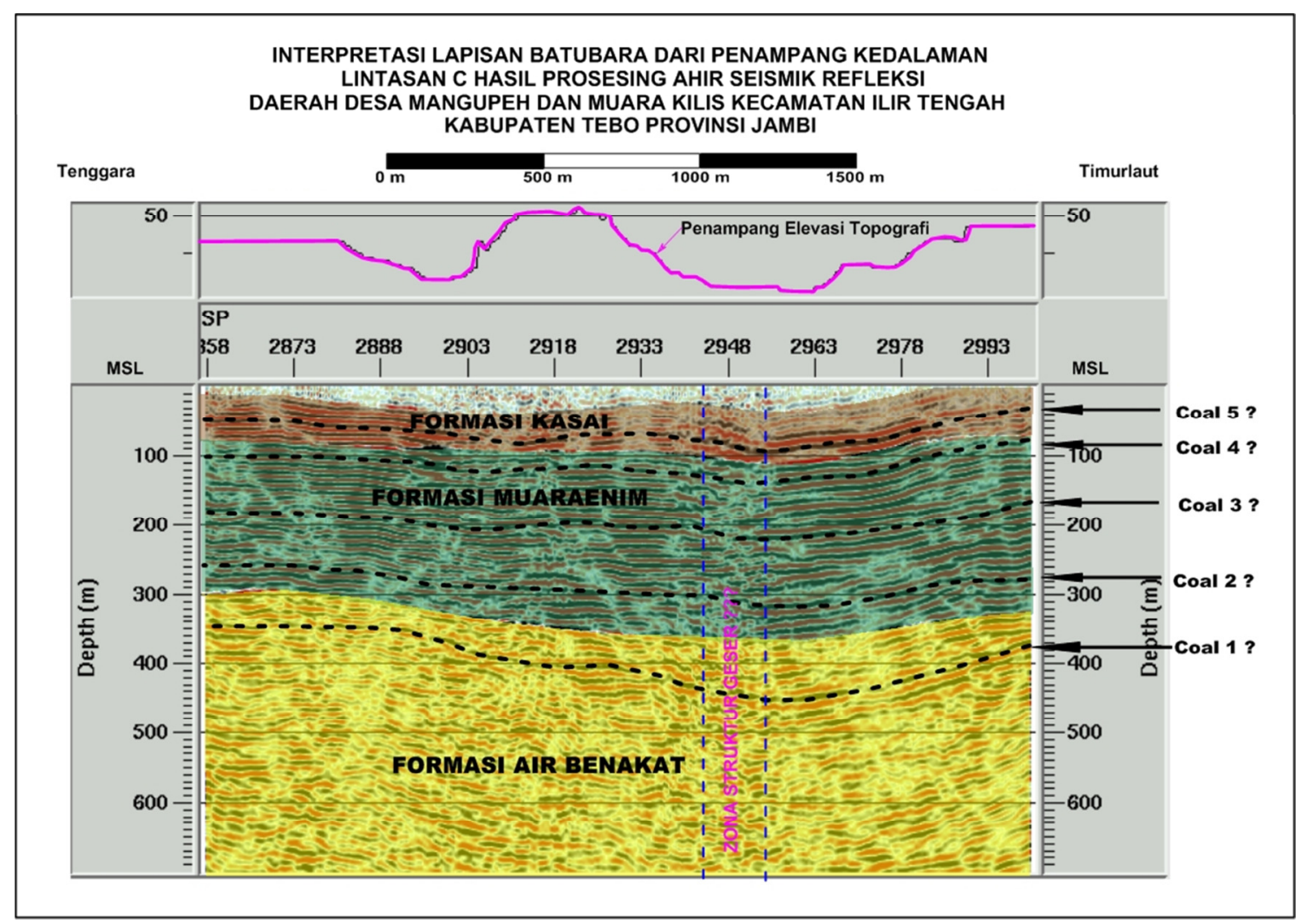

Gambar 13. Pendugaan Lapisan Batubara Lintasan C. 


\section{MAKALAH ILMIAH}

\section{KESIMPULAN}

Dari hasil penyelidikan seismik refleksi batubara di Desa Mangupeh dan Muara Kilis, Kecamatan Ilir Tengah Kabupaten Tebo Provinsi Jambi, dapat disimpulkan bahwa penampang Lintasan A dan Lintasan $C$ memberikan informasi bawah permukaan yang hampir sama terutama pada posisi pendeteksian kedalaman $\pm 450 \mathrm{~m}$ dan diduga terdapat lima lapisan batubara yang ketebalannya tidak dapat ditentukan. Lapisan batubara tersebut diperkirakan termasuk dalam Formasi Airbenakat, Formasi Muaraenim, dan Formasi Kasai, selain itu dari cepat rambat gelombang yang rendah diperkirakan terdapat struktur geologi berupa struktur patahan/sesar.

\section{UCAPAN TERIMA KASIH}

Penulis mengucapkan terima kasih kepada Tim Penyelidikan Seismik Refleksi daerah Tebo Tengah Kabupaten Tebo Provinsi Jambi yang telah mengizinkan untuk menggunakan data dan penafsiran laporan hasil penyelidikan untuk dijadikan makalah Buletin Sumber Daya Geologi sehingga kedua penulis dapat menyelesaikan tulisan ini menjadi makalah ilmiah. Alasan pemilihan laporan ini disebabkan penyelidikan seismik refleksi jarang dilakukan dalam eksplorasi batubara secara khusus. Terima kasih juga untuk rekan-rekan yang mnemberikan saran dalam penyempurnaan makalah ini terutama para pengelola Buletin Sumber Daya Geologi Pusat Sumber Daya Geologi.

\section{DAFTAR PUSTAKA}

Anonim, 2010, Laporan Penyelidikan Batubara Bersistem Pada Cekungan Sumatera Selatan, Daerah Sumai, Kabupaten Tebo, Provinsi Jambi, Pusat Sumber Daya Geologi, Bandung.

Anonim, 2013, Laporan Akuntabilitas Kinerja Instansi Pemerintah Pusat Sumber Daya Geologi 2013, PSDG Bandung, 145 halaman.

Darman, H., dan Sidi, F. H., 2000, An Outline Of The Geology of Indonesia, Ikatan Ahli Geologi Indonesia.

De Coster, G.H., 1974, The Geology of the Central and South Sumatera Basin, Indonesia Petroleum Assosiation, 3rd Ann. Conv, Proceeding.

Diessel, C.F.K.,1984, Coal geology, Workshop Course 274/84, Australian Mineral Foundation, 20-24 ${ }^{\text {th }}$ February 1984, Indonesia.

Lyatsky H.V. dan Lawton, D.C., 1988, "Application Of The Surface Reflection Seismik Method To Shallow Coal Exploration In The Plains Of Alberta", Canadian Journal of Geophysics, Vol 24. No. 2

Simandjuntak, T.O., Buditrisna, T., Surono, Gafoer, S., dan Amin, T.C., 1994. Peta Geologi Lembar Muarabungo, Sumatera., Skala 1:250,000. Pusat Penelitian Pengembangan Geologi, Bandung. 